\title{
CAMBRIAN-LOWER ORDOVICIAN BOUNDARY BEDS IN NORTHERN POLAND
}

The Ordovician deposits in the Polish part of the peri-Baltic syneclise are known from numerous borings (Bednarczyk, 1968, 1979; Modliński, 1973). They are represented by lithofacies types that are characteristic of the facies zones distinguished in Baltoscandia by Männil (Мянниль, 1966) and later specified by Jaanusson (1976). The first of them - the Scanian confacies belt - extends to the Leba area (the westernmost part of the peri-Baltic syneclise), and the second one - the central Baltoscandian confacies belt - reaches the eastern part of the peri-Baltic syneclise, including the northeastern part of Poland (Fig. 1).

In the Leba area the Lower Ordovician begins with claystones intercalated with beds of glauconitic grey limestones with conodonts of the Paltodus deltifer Zone (Bednarczyk, 1979) that overlies concordantly the Upper Cambrian black claystones of the Acerocare Zone (Figs 1 and 2, see the Białogóra 1 section) or starts with variable in thickness glauconitites layers grading upward into claystones of the Tetragraptus phyllograptoides Zone? (Fig. 2, the Białogóra 2 and Zarnowiec-IG1 sections) or into the similar sediments of the Didymograptus balticus Zone (Fig. 2, the Dẹbi 2 and Dębki 3 and Piaśnica 2 sections). In this area the Lower Ordovician deposits cover various members of the Upper Cambrian claystones intercalated of limestone with trilobite of the Agnostus pisiformis or the Peltura scarabeoides Zone (Fig. 2).

In contrast to the Lower Ordovician of the Leba area, the coeval deposits in the eastern part of the peri-Baltic syneclise consist of sandycarbonate rocks. In some sections the Lower Tremadocian starts with sandy-conglomeratic deposits with Obolus apollinis, and in other profiles the Lower Arenigian begins with glauconitites of the Prioniodus elegans Zone or even more frequently with the glauconitites passing upwards

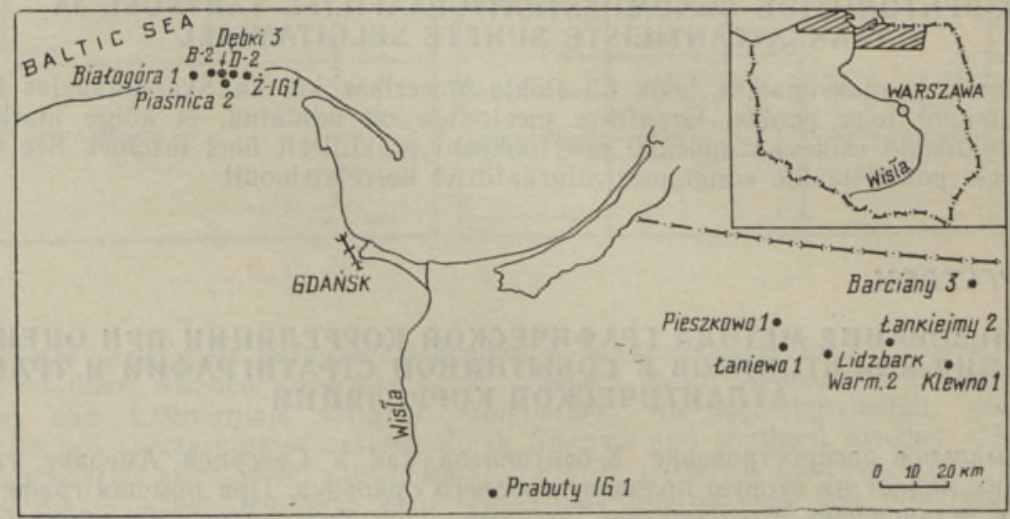

Fig. 1. Location of boreholes (oblique lines - investigated area). 
into the glauconitic limestones with conodonts of the Oepikodus evae Zone (Fig. 3). The Lower Ordovician of this territory overlies in places the Upper Cambrian sandy-carbonate deposits with trilobites of the Agnostus pisiformis Zone or more often the Middle Cambrian sandstones (Bednarczyk, 1984; Lendzion, 1983).

On the basis of the above-mentioned data one can distinguish several sedimentary episodes in the section embracing the Upper Cambrian up to the Lower Ordovician in the northeastern part of Poland. These episodes appear to be connected with the transgressive-regressive events distinguished by Miller (1984) and Erdtmann (1986). Similar phenomena were observed in the Upper Cambrian to the Lower Ordovician sections in the rest of the territory of Poland (Fig. 4) (Biernat, Bednarczyk, in prep.).

These are as follows: 1) uppermost Cambrian-Lowermost Tremadocian regression coinciding with Acerocare Regressive Event (ARE) of Erdtmann (1986) or Lange Ranch Eustatic Event (LREE) of Miller (1984); 2) Upper Tremadocian transgressive phase preceded by a regression connected with Peltocare Regressive Event (PRE) of Erdtmann (1986) or Black Mountain Regressive Event of Miller (1984). This phase is characterized by muddy-silty-glauconitic or marly-glauconitic sediments in the Polish part of the East-European craton or by siliceous rocks in the Holy Cross Mts (Bednarczyk, 1971). The sediments contain rich and diversified faunas (inarticulata, graptolites, trilobites and conodonts); 3) Tremadocian-Arenigian transgressive-regressive phase with carbonate and/or sandy-carbonate (with glauconite) sedimentation. There are many stratigraphic gaps, usually local, sometimes very short and in some places a certain sedimentary stagnation has been stated and probably connected with a deep erosion. This phase is connected with the Ceratopyge Regressive Event (CRE) of Ertdmann (1986); 4) regressive phase at the end of the Billingen and before the sedimentation of the Volkhovian deposits may be connected with the Valhall Regressive Event (VRE) of Erdtmann (1986) (Fig. 4).

The transgressive-regressive phases in the Lower Ordovician of Poland mentioned above are in the author's opinion a reflection of eustatic changes of sea level and considerable climatic alterations caused by subsequent intensification of glacial periods.

In some cases the sedimentation of the Upper Cambrian to the Lower Ordovician deposits was broken up by the intermitted period of the intensity of uplifting block movements in the substratum but these factors were only of secondary importance as compared to the above-mentioned agent.

\section{REFERENCES}

Bednarczyk, W. The Ordovician in the region of Ketrzyn (NE Poland) // Acta Geol. Polon., 1968, XVIII, N 4, 707-749 (in Polish, English summary).

Bednarczyk, W. Stratigraphy and palaeogeography of the Ordovician in the Holy Cross Mts: // Acta Geol. Polon., 1971, 21, N 4, 573-616.

Bednarczyk, W. Upper Cambrian to Lower Ordovician conodonts of the Leba Elevation, NW Poland, and their stratigraphic significance // Acta Geol. Polon., 1979, 29,

Bednarczyk, W. Biostratigraphy of the Cambrian deposits in the Leba area // Acta Geol. Polon., 1984, 34, N 3-4, 95-110.

Erdtmann, G.-D. Early Ordovician eustatic cycles and their bearing on punctuations in early nematophorid/planktic graptolite evolution // O. H. Walliser (ed.). Global

Bioevents. Lecture Notes in Earth Sciences, 8. Berlin-Heidelberg, 1986, 139-152.
Jaanusson, V. Faunal dynamics in the Middle Ordovician (Viruan) of Balto-Scandia // $M$. G. Bassett (ed.). The Ordovician System. Proc. Palaeont. Ass. Symp. Bir-
mingham, 1974. Cardiff, 1976, 301-326.

Lendzion, $K$. Biostratigraphy of the Cambrian deposits in the Polish part of the EastEuropean platform // Kwart. Geol., 1983, 27, N 4, 669-694. 
Miller, J. F. Cambrian and earliest Ordovician conodont evolution, biofacies, and provincialism // D. L. Clark (ed.). Conodont Biofacies, and Provincialism. Geol. Soc. America. Spec. Pap., 1984, N 196, 43-68.

Modliński, Z. Stratigraphy and development of the Ordovician in north-eastern Poland /I I. G. Prace, $1973, \mathrm{~N} 72,8-74$.

Мянниль Р. М. История развития Балтийского бассейна в ордовике. Таллин, 1966.

Polish Academy of Sciences,

Institute of Geological Sciences
Received

Dec. 20,1988

\section{W. BEDNARCZYK}

\section{KAMBRIUMI JA ALAMORDOVIITSIUMI PIIRIKIHID POHJA-POOLAS}

Piirikihtide kivimilise ja faunistilise koostise muutumise alusel on eristatud läbilōike tekkel neli sündmust: 1) regressioon kambriumi lõpul ja Tremadoci algul; 2) transgressioon ja regressioon Hilis-Tremadocis; 3) transgressioon ja regressioon Tremadoci ja Arenigi vahetusel ja 4) regressioon Billingeni aja lõpul.

\section{В. БЕДНАРЧИК}

\section{ПОГРАНИЧНЫЕ СЛОИ КЕМБРИЯ И ОРДОВИКА В СЕВЕРНОИ ПОЛЬШЕ}

На основе изменений литологического и фаунистического составов пограничных отложений в разрезе выделяются следующие события: 1. регрессия в конце кембрия и начале тремадока; 2. трансгрессия-регрессия в позднем тремадоке; 3. трансгрессиярегрессия при переходе от тремадока в арениг; 4. регрессия в конце биллингена. 